Bill Y. Ong MD FRCP(C), Ralph Yarnell MD FRCP(c), William A. Tweed MD FRCP(C), Daniel S. Sitar PH D

\title{
Foetal responses to acute haemorrhage under halothane anaesthesia
}

The effect of halothane anaesthesia on the foetal responses to acute haemorrhage was studied in chronically prepared ewes. An average of $27.9 \mathrm{ml} \cdot \mathrm{kg}^{-1}$ of foetal blood was withdrawn resulting in an acute 20 per cent decrease in mean arterial pressure which returned toward the control value after 186 seconds. After the blood loss, cardiac output was reduced by 26.1 per cent and heart rate decreased by 26 per cent. Blood flows to the kidneys, placenta and musculoskeletal structures were reduced by $24.7,38.2$ and 35.3 per cent respectively but flow to the brain increased by 30 per cent. Reinfusion of lost blood, corrected flow reductions and the supply to the gastrointestinal organs increased above control values. This study showed that foetal lambs were able to tolerate an acute blood loss under halothane anaesthesia. An adequate perfusion pressure and blood flow to critical organs, such as the brain was maintained by increasing systemic vascular resistance. The compensation, however, was incomplete. Placental blood flow. maternal-foetal gas exchanges, and redistribution of cardiac output away from gastrointestinal tract and skin were impaired.

\section{Key words}

ANAESTHESIA: obstetric; ANAESTHETIC: volatile: halothane; BLOOD: loss; BRAIN: blood flow; HAEMORRHAGE, TOXICITY: foetal.

From the Department of Anesthesia, Health Sciences Centre and Clinical Pharmacology Section, Faculty of Medicine, University of Manitoba.

Reprint requests to: Dr. B.Y. Ong, Department of Anesthesia, Health Sciences Centre-Gencral, 700 William Avenue, Winnipeg, Manitoba, Canada R3E 0Z3.

This project was supported by St. Boniface General Hospital Rescarch Foundation, Grant RF 81-13.
Some neonates suffer acute blood losses during or immediately after birth. These can occur with accidents to the umbilical cord, placenta praevia, abruptio placentae or the incision into the placent: during Caesarean section. ${ }^{1,2}$ Many of these neonates are also exposed to anaesthetic agents when emergency Caesarean sections are performed. In the future, intrauterine foetal surgery may become common. To care for these neonates, the impact of anaesthetic agents on the ability of the foetus to respond to acute blood loss must be understood. Nuwayhid et $a l^{3}$ found that pentobarbital impaired foetal lamb's ability to compensate for acute blood loss. Other anaesthetic agents have not been evaluated. Therefore, we investigated the response of foetal lambs to acute haemorhage under halothane anaesthesia.

\section{Methods}

Eight foetuses of 120 to 135 days gestation were studied. Surgical preparation was done under halothane and oxygen anaesthesia with controlled ventilation via an endotracheal tube. Femoral arterial and venous catheters were inserted in the ewe. A small hysterotomy was performed through a midline abdominal approach, to expose the foetus. Femoral arterial and venous catheters were inserted into the foetus and advanced to the descending aorta and inferior vena cava respectively. An axillary artery catheter was inserted and advanced to the common brachiocephalic trunk. The incisions were closed and all catheters brought subcutaneously to a pocket on the ewe's flank. Mother and foetus were given prophylactic antibiotics (penicillin and gentamicin) and allowed to recover to a stable state (48-72 hours) before the studies. Foetal arterial blood gases were measured each day and only foetuses with arterial $\mathrm{pH}$ greater than 7.30 and $\mathrm{PaO}_{2}$ greater than $2 \mathrm{kPa}$ were studied. 
Foetal and maternal arterial blood pressures and foetal venous pressures were recorded continuously with Statham P23 pressure transducers and an Hewlett-Packard Dynograph. Maternal femoral and foetal ascending aortic blood gases were measured with a Corning, Model 165, blood gas analyzer. On the day of the study, a tracheostomy was performed on the ewe under halothane-oxygen anaesthesia by mask for 5-10 minutes. Then the ewe breathed humidified oxygen through the tracheostomy for 30 minutes. During this time, the cardiovascular systems of the ewe and foetus were monitored contimuously and their blood gases were measured to ensure stability of the preparation. Then halothane was introduced into the maternal breathing circuit, and the inspired concentration was maintained at 1.5 per cent and monitored on a Beckman LB2 infrared analyzer. The ewe's lungs were ventilated mechanically with an Ohio Anaesthetic ventilator and her $\mathrm{PaCO}_{2}$ was maintained at the control value.

After one hour, maternal and foetal blood samples were obtained from the maternal femoral artery and foetal brachiocephalic artery for analysis of halothane concentrations and blood gases. Matcmal and foetal blood pressures and heart rates as well as foetal haematocrit were determined. Foetal organ blood flows were measured by a microsphere technique $\mathrm{e}^{4.5}$, using $15 \mu \mathrm{m}$ diameter microspheres labelled with gamma emitting $\mathrm{Ce}^{141}, \mathrm{Cr}^{51}$, or $\mathrm{Sr}^{45}$. For each measurement, approximately one million spheres were injected into the inferior vena cava over 30 seconds. Arterial blood samples were withdrawn at a fixed rate, $1.94 \mathrm{ml} / \mathrm{min}$, from brachiocephalic and descending aortic catheters beginning thirty seconds before the injection and continuing for a total of 180 seconds.

Foetal arterial blood was then withdrawn at a rate of $15 \mathrm{ml} / \mathrm{min}$ until mean arterial pressure was reduced by 20 per cent. A complete second set of measurements was made after stabilization for 15 minutes under hypotensive conditions. The blood was then reinfused, and after 15 minutes, a third set of measurements was made.

At the end of the experiment, mother and foetus were anaesthetized with sodium thiopentone and then killed with potassium chloride solution. The foetus was autopsied, to validate catheter placement, and foetal organs were separated, weighed and ashed.

Radionuclide levels in the blood samples and ashed tissue samples were counted in a Searle gamma well counter. The following equation was used to calculate organ blood flow:

$$
F=\frac{F a \times \text { i organ }}{i \text { arterial }}
$$

$\mathrm{F}=$ organ blood flow $(\mathrm{ml} / \mathrm{g} / \mathrm{min}) ; \mathrm{Fa}=$ withdrawal rate of reference arterial blood sample; $i$ organ = microsphere content of organ tissue $(\mathrm{cpm} / \mathrm{g}$ ); i arterial $=$ microsphere content of total reference arterial blood sample (cpm)

Blood flow to the lung could not be measured because there was no reference sample for pulmonary arterial blood. The hepatic-yenous contribution to total liver blood flow was not measured because those microspheres were trapped in the gut before reaching the hepatic vein.

Biventricular cardjac output $(\mathrm{CO})$ was calculated by addition of blood flows to all organs except the lung. Previous studies indicated that this would result in an underestimation of the true cardiac output by $4-5$ per cent. ${ }^{5}$

Halothane concentrations were measured by gasliquid chromatography as described previously. ${ }^{6}$ Briefly, blood samples were transferred to vials the openings of which were sealed with teflon caps. Chloroform was added to each sample as an internal standard and the solutions were equilibrated in a $37^{\circ} \mathrm{C}$ water bath. Ratio of peak heights (halothane vs. chloroform) was used to determine concentration of halothane in each sample.

For statistical analysis of the data, analysis of variance and Student's paired $t$ test with each foetus serving as its own control, were used. A $P$ value of 0.05 or less was considered significant. All data are presented as mean \pm S.D.

Results

The eight foetuses and their placentae had an average weight of $3.1 \mathrm{~kg}$. Blood removed was within the range of $50 \mathrm{ml} t 0100 \mathrm{ml}$, with a mean of $86.7 \mathrm{ml}$. This was equivalent to $27.9 \mathrm{mg} \cdot \mathrm{kg}^{-1}$ of fuetal-placental weight. Maternal and foetal arterial blood halothane and blood gas values are listed in Table I. Foetal haematocrits during control, hypovolemic and post-reinfusion states were $37.1 \pm 2.8$ per cent, $35.3 \pm 3.0$ per cent and $37.3 \pm 5.3$ per cent respectively. The differences were not significant. 
TABLE I Maternal and foetal arterial blood halothane and blood gas values in the awake state, during control period, after blond withdrawal and after reinfusion (n $=8$ ) mean $\pm S D$

\begin{tabular}{|c|c|c|c|c|}
\hline & \multirow{2}{*}{$\begin{array}{l}\text { Awake } \\
\text { Breathing } \\
100 \% \mathrm{O}_{2}\end{array}$} & \multicolumn{3}{|c|}{ Under halothane anaesthesia } \\
\hline & & $\begin{array}{l}\text { Contral } \\
\text { period }\end{array}$ & $\begin{array}{l}\text { After blood } \\
\text { withdrawal and } \\
\text { stabilization }\end{array}$ & $\begin{array}{l}\text { After blood } \\
\text { reinfusion and } \\
\text { stabilization }\end{array}$ \\
\hline \multicolumn{5}{|l|}{ A. Maternal } \\
\hline Halothane $(\mathrm{mg} / \mathrm{L})$ & 0 & $101.6 \pm 7.8$ & $103.0 \pm 11.9$ & $117.6 \pm 13.5$ \\
\hline $\mathrm{pH}$ & $7.47 \pm 0.03$ & $7.47 \pm 0.03$ & $7.46 \pm 0.03$ & $7.45 \pm 0.02$ \\
\hline $\mathrm{PO}_{2}(\mathrm{kPa})$ & $34.4 \pm 13.6$ & $46.9 \pm 3.9$ & $50.4 \pm 3.9$ & $50.7 \pm 3.6$ \\
\hline $\mathrm{PCO}_{2}(\mathrm{kPa})$ & $4.1 \pm 0.8$ & $4.0 \pm 0.3$ & $4.3 \pm 0.3$ & $4.4 \pm 0.3$ \\
\hline \multicolumn{5}{|l|}{ B. Foetal } \\
\hline Halothane $(\mathrm{mg} / \mathrm{L})$ & 0 & $68.8 \pm 6.6$ & $70.1 \pm 8.8$ & $81.9 \pm 9.5$ \\
\hline $\mathrm{pH}$ & $7.39 \pm 0.04$ & $7.32 \pm 0.07 \dagger$ & $7.24 \pm 0.11 \dagger$ & $7.22 \pm 0.13 \dagger$ \\
\hline $\mathrm{PO}_{2}(\mathrm{kPa})$ & $2.8 \pm 0.5$ & $3.2 \pm 0.1$ & $3.2 \pm 0.1$ & $3.4 \pm 0.2$ \\
\hline $\mathrm{PCO}_{2}(\mathrm{kPa})$ & $5.7 \pm 1.1$ & $6.0 \pm 0.9$ & $6.7 \pm 1.3^{*}$ & $7.0 \pm 1.0^{*}$ \\
\hline
\end{tabular}

$* \mathrm{P}<0.05$ compared to awake period

$\dagger P<0.01$ compared to awake period

TABLE Il Matemal blood pressures and hewr rates in the awake state, under halothane anaesthesia after withdrawal of foetal blood and after reinfusion $(n=8)$ mean \pm SD

\begin{tabular}{|c|c|c|c|c|}
\hline & \multirow{2}{*}{$\begin{array}{l}\text { Awake } \\
\text { Breathing } \\
100 \% \mathrm{O}_{2}\end{array}$} & \multicolumn{3}{|c|}{ Under halothane anaesthesia } \\
\hline & & $\begin{array}{l}\text { Control } \\
\text { period }\end{array}$ & $\begin{array}{l}\text { After withdrawal } \\
\text { of foelal blood }\end{array}$ & $\begin{array}{l}\text { After } \\
\text { reinfusion }\end{array}$ \\
\hline $\begin{array}{l}\text { Matemal blood } \\
\text { pressure }(\mathrm{kPa})\end{array}$ & $12.1 \pm 1.9$ & $12.7 \pm 0.4$ & $12.4 \pm 0.5$ & $12.5 \pm 0.5$ \\
\hline $\begin{array}{l}\text { Heart rate } \\
\text { (beats/minute) }\end{array}$ & $114.1 \pm 17.3$ & $102.4 \pm 3.4$ & $97.3 \pm 4.1$ & $98.6+5.1$ \\
\hline
\end{tabular}

Maternal mean arterial blood pressures and heart rates did not change with foetal blood loss or reinfusion (Table II).

Foetal haemodynamic values are listed in Table III. The lowest and highest blood pressures were obtained immediately after blood withdrawal and reinfusion. Blood pressures then returned towards control values. At the end of the 15 minute stabilization periods, mean arterial blood pressures were not significantly different from control values. An average of $185.7 \pm 66.3$ seconds was required for blood pressure to stabilize after acute blood withdrawal. After reinfusion, the required time was $368.6 \pm 70.3$ seconds. These values were significantly different $(\mathrm{p}<0.01)$. Mean calculated cardiac output was reduced by 26.1 per cent with blood loss. Foetal heart rate also decreased 26 per cent.
Blood flows to different organs are shown in Figure 1. Flow to the kidneys, placenta and musculoskeletal structures was significantly reduced after blood loss. In contrast, flow to the brain, increased. After reinfusion of lost blood, flow reductions were corrected and flow to gastrointestinal organs increased above control levels.

Distribution of cardiac output to different organs is illustrated in Figure 2. The brain and gastrointestinal organs received a greater percentage of the cardiac output during the hypovolemic state. Gastrointestinal organs continued to receive a larger component of the cardiac output after reinfusion.

\section{Discussion}

The major change produced by acute blood loss was a decrease in cardiac output. Creasy et al. ${ }^{7}$ found that foetal-placental blood volume was $135 \mathrm{mg} \cdot \mathrm{kg}^{-1}$ 
TABLE III Foetal arterial blood pressures, ycnous pressures, heart rates and cardiac outpuls in awake state, control period under halothane anaesthesia, after blood withdrawal and reinfusion $(n=8)$ mean \pm SD

\begin{tabular}{|c|c|c|c|c|c|c|}
\hline & \multirow[b]{2}{*}{ Awake } & \multicolumn{4}{|c|}{ Under halothane anaesthesia } & \multirow[b]{2}{*}{$\begin{array}{l}\text { After blood } \\
\text { reinfusion \& } \\
\text { stabilization }\end{array}$} \\
\hline & & $\begin{array}{l}\text { Control } \\
\text { periad }\end{array}$ & $\begin{array}{l}\text { Immediately } \\
\text { after blood } \\
\text { withdrawal }\end{array}$ & $\begin{array}{l}\text { After blood } \\
\text { withdrawal and } \\
\text { stabilization }\end{array}$ & $\begin{array}{l}\text { Immediately } \\
\text { after blood } \\
\text { reinfusian }\end{array}$ & \\
\hline $\begin{array}{l}\text { Arterial blood } \\
\text { pressure }(\mathrm{kPa})\end{array}$ & $7.9 \pm 0.7$ & $6.8 \pm 0.9 \ddagger$ & $5.3 \pm 0.97 \neq$ & $6.3 \pm 0.8 \neq$ & $8.5 \pm 0.9$ & $7.0 \pm 0.7$ \\
\hline $\begin{array}{l}\text { Venous pressure } \\
(\mathrm{kPa})\end{array}$ & & $1.6 \pm 0.5$ & $1.2 \pm 0.4 \dagger$ & $1.2 \pm 0.4 \dagger$ & $2.0 \pm 0.7$ & $1.3 \pm 0.5$ \\
\hline $\begin{array}{l}\text { Heart rate } \\
\text { (beats/minute) }\end{array}$ & $165.5 \pm 20.0$ & $149.5 \pm 17.5$ & $112.6 \pm 21.3 \dagger$ & $110.6 \pm 11.6 \dagger$ & $129.6 \pm 16.0^{*}$ & $144.7 \pm 7.6$ \\
\hline $\begin{array}{l}\text { Cardiac output } \\
\text { (ml/min) }\end{array}$ & & $901.5 \pm 147.1$ & & $666.5 \pm 224.8 \dagger$ & & $927.0 \pm 206.4$ \\
\hline
\end{tabular}

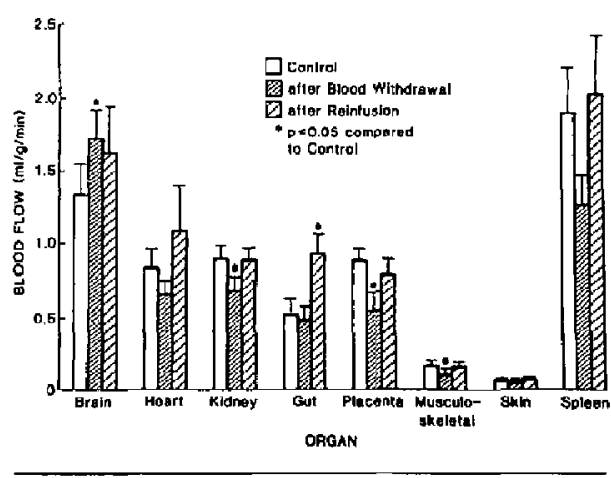

FIGURE 1 Foetal organ blood flows during control period, after blood withdrawal and after reinfusion. Each bar represents the mean of eight values $=\mathbf{S E}$.

in lambs. Thus, the $86.7 \mathrm{ml}$ removed would then decrease blood volume by an average 20.7 per cent. In previous studies ${ }^{8-10}$ of unanacsthetized foetal lambs, average reductions in cardiac outputs were $20.4,26.6$ and 40 per cent with losses of 10,15 and 20 per cent of estimated blood volume respectively. The 26.1 per cent reduction in cardiac output that we observed, is comparable to those changes found in the unanacsthetized state. Venous pressure decreased by 29.3 per cent and was the most likely cause of the reduced cardiac output. Kirkpatrick et $a l^{11}$ had found that the Frank-Starling mechanism was an important determinant of foetal cardiac output.

The 8.6 per cent reduction in blood pressure was smaller than the decrease in cardiac output. Therefore, systemic vascular resistance increased. Translocation of fluid from the maternal circulation or extracellular fluid compartment probably did not play a role in the acute response because foetal haemalocrit was unchanged. In contrast, in unanaesthetized lambs, Tweed et al. ${ }^{10}$ and Faber et al. ${ }^{12}$ noted a decrease in foetal haematocrit with acute blood loss.

Reduction in heart rate was the most consistent feature observed during hypovolaemia. In previous studies, ${ }_{2}^{3,8,10,13,14}$ heart rates have been reported to increase, decrease or remain unchanged with acute changes in blood volume. The conflicting results were probably a result of differences in magnitude of blood volume changes, presence of other anaesthetic agents and effects of concomitant surgical stress. Interactions of different cardiovascular reflexes might also be responsible. The baroreceptor reflex, if activated by the initial fall in blood pressure would cause an increase in heart rate. ${ }^{15,16}$ The aortic chemoreceptor could be stimulated by an increasc in arterial hydrogen ion activity or a decrease in oxygen delivery associated with the reduced cardiac output. ${ }^{17}$ The reduction of heart rate and the increased systemic yascular resistance were consistent with aortic chemoreceptor stimula- 
TABLE IV Foetal cardiac output and organ blood flows and their changes with blood loss expressed as percent of control vatues

\begin{tabular}{|c|c|c|c|c|}
\hline & \multicolumn{2}{|l|}{ Awake' } & \multicolumn{2}{|c|}{ Under halothane anaesthesia ${ }^{2}$} \\
\hline & Control & $\begin{array}{l}\text { Change with } \\
\text { blood loss (\%) }\end{array}$ & Control & $\begin{array}{l}\text { Change with } \\
\text { blood loss (\%) }\end{array}$ \\
\hline $\begin{array}{l}\text { Cardiac output } \\
\left(\mathrm{ml} \cdot \mathrm{kg}^{-1} \cdot \mathrm{min}^{-1}\right)\end{array}$ & 375 & -40.5 & 291 & -26.1 \\
\hline $\begin{array}{l}\text { Organ blood flow } \\
\left(\mathrm{ml} \cdot \mathrm{g}^{-1} \cdot \mathrm{min}^{-1}\right) \\
\text { brain } \\
\text { heart } \\
\text { kidneys } \\
\text { gut }\end{array}$ & $\begin{array}{l}1.17 \\
1.69 \\
1.85 \\
0.94\end{array}$ & $\begin{array}{r}-9.4 \\
-30.2 \\
-43.2 \\
-44.7\end{array}$ & $\begin{array}{l}1.33 \\
0.84 \\
0.89 \\
0.52\end{array}$ & $\begin{array}{r}+30.1 \\
-22.6 \\
-24.7 \\
-7.7\end{array}$ \\
\hline Musculoskeletal & 0.22 & $-\$ 4.5$ & 0.17 & -35.3 \\
\hline Skin & 0.18 & -50.0 & 0.07 & -14.4 \\
\hline Placenta & 0.85 & -29.4 & 0.89 & -38.2 \\
\hline
\end{tabular}

'From reference $10(n=8)$.

${ }^{2}$ From this present study $(n=B)$.

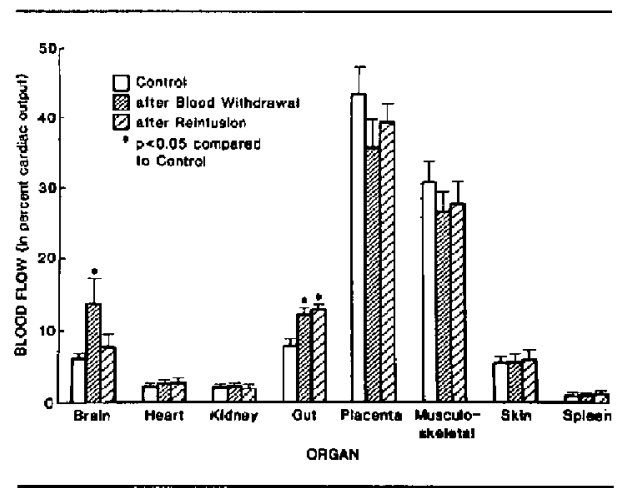

FIGURE 2 Percentages of the cardiac output distributed to individual foetal organs during control period, after blood withdrawal and after reinfusion. Each bar represents the mean of 8 values $\pm S E$.

tion. ${ }^{19,20}$ The baroreceptor reflex did not appear to play a major role in cardiovascular control under these experimental conditions, which is in agreement with the findings of Faber et al. ${ }^{12}$ in unanaesthetized lambs. Chemoreceptor responses might have been elicited by changes in blood flow rather than blood gas concentrations. After reinfusion, heart rates and systemic vascular resistances retumed to control values without detectable changes in blood gas values.
Cardiac output and organ blood flows from this study and from a previous study ${ }^{10}$ from our laboratory are compared in Table IV. The two studies followed a similar protocol except for anacsthesia. Changes with blood loss are expressed as percentages of control values. The major differences were changes in blood supply to the brain, gastronintestinal organs and skin.

In this study, blood flow to the brain increased during the hypovolemic period both in terms of the actual measured flow and as a percentage of cardiac output, probably as a result of an increase in arterial carbon dioxide tension. With blocd loss, flow to the brain increased by $0.28 \mathrm{ml} \cdot \mathrm{g}^{-1} \cdot \mathrm{min}^{-1}$ while $\mathrm{PaCO}_{2}$ increased by $0.64 \mathrm{kPa}$ or $0.44 \mathrm{ml} \cdot \mathrm{g}^{-1} \cdot \mathrm{min}^{-1}$ for each $\mathrm{kPa}$ increase in $\mathrm{PaCO}_{2}$. In acutely exteriorized foetal lambs, Purves and James ${ }^{18}$ estimated that cerebral blood flow increased $0.18 \mathrm{ml} \cdot \mathrm{g}^{-1} \cdot \mathrm{min}^{-1}$ with each $\mathrm{kPa}$ increase in $\mathrm{PaCO}_{2}$. Rosenberg et $a l^{21}$ found that in chronically prepared foetal lambs cerebral blood flow increased by $0.26 \mathrm{ml} \cdot \mathrm{g}^{-1} \cdot \mathrm{min}^{-1}$ for each $\mathrm{kPa}$ increase in $\mathrm{PaCO}_{2}$. Alexander et al. ${ }^{22}$ suggested that halothane anaesthesia potentiated the cerebrovascular response to hypercapnia in adult man. Therefore, the observed difference may be explained by the experimental conditions of the studies, that is, halothane anaesthesia plus increased $\mathrm{PCO}_{2}$. Previous studies, ${ }^{8-10}$ without any increase in $\mathrm{PaCO}_{2}$, did not show an increase in 
cerebral blood flow but the proportion of cardiac output distributed to the brain was greater in the hypovolemic state.

In unanaesthetized lambs, perfusion of gastrointestinal organs and skin were markedly reduced during hypovolaemia. ${ }^{8-10}$ Under halothane anaesthesia, fows to the intestines and skin decreased only slightly. The percentage of the cardiac output going to the gastrointestinal tract actually increased after blood loss, but the mechanism responsible for selective vasodilatation is unknown. Since the cerebral and mesenteric circulations were the only ones to exhibit such changes, carbon dioxide or halothane anaesthesia might have played a role.

Reductions in blood flows to the kidneys, placenta and musculoskeletal structures were similar to those reported previously in unanaesthetized lambs. ${ }^{8-10.23}$ Placental blood flow decreased by an average of 1.8 per cent with each 1 per cent reduction in blood volume, which is similar to the value of 1.7 per cent reported by Faber $e t a l^{23}$ in unanaesthetized foetal lambs. This reduction in placental blood flow impaired maternal and foetal blood gas exchange and produced a foetal respiratory acidaemia.

In conclusion, foetal lambs were able to tolerate an acute loss of 20 per cent of their blood volume under halothane anaesthesia. They compensated for the reduced cardiac output by increasing systemic vascular resistance and thercby maintain an adequate perfusion pressure and blood flow to critical organs such as the brain. However the compensation was incomplete. Placental blood flow and hence, matemal-foetal gas exchange were adversely affected. Halothane anaesthesia also impaired redistribution of the cardiac output from the gastrointestinal tract and skin in response to hypovolemia. However, halothane did not affect vasoconstriction in the carcass and kidneys after acute blood loss. Cerebral vascular dilatation occurred, in response to halothane and hypercapnia, and resulted in increased cerebral blood flow and oxygen delivery to the brain.

\section{Acknowledgements}

The authors thank Ms. M. Cumming, Mr. W. Pucci and $\mathrm{Mr}$. K. Gregory for their technical assistance and Miss K. Morin for preparation of this manuscript.

\section{References}

1 Lubin $B$. Neonatal anaemia secondary to blood loss. Clin Haematol 1978; 7: 19-34.

2 Kirkman HN, Riley HD Jr. Posthemorrhagic anemia and shock in the newbon. Pcdiatrics 1959; 24: $97-105$.

3 Nuwayhid B, Vaughn D, Brinkman CR III, Assali NS. Circulatory shock in pregnant sheep IV. Fetal and neonatal circulatory responses to hypovolemia influence of anaesthesia. An J Obstet Gynecol 1978; 132: 658-66.

4 Hales JRS. Radioactive microsphere techniques for studies of the circulation. Clin Exp Pharmacol Physiol (Suppl.) 1974; 1: 31-46.

5 Rudolph AM, Heymann MA. The circulation of the fetus in utero-methods for studying distribution of blood flow, cardiac output, and organ blood flow. Circ Res 1967; 21: 163-83.

6 Gregory GA, Wade IG, Biehl DR, Ong BY, Sitar $D S$. Fetal anesthetic requirement (MAC) for halothane. Anesth Analg 1983; 62: 9-14.

7 Creasy RK, Drost $M$, Green NW, Morris JA. Determination of fetal, placental, and neonatal blood volumes in the sheep. Circ Res 1970; 27: 487-94.

8 Gilbert RD. Cantrol of fetal cardiac output during changes in blood volume. Am J Physiol 1980; 238: $\mathrm{H80}-\mathrm{H} 86$.

9 Toubas PL, Silverman NH, Heymann MA, Rudolph $A M$. Cardiovascular effects of acute hemorrhage in fetal lambs. Am J Physiol 1981; 240: H45-H48.

10 Tweed WA, Cote J, Wade JG, Gregory G, Mills $A$. Preservation of fetal brain blood flow relative to other organs during hypovolemic hypotension. Pediatr Res 1982; 16: 137-40.

11 Kirkpatrick SE, Pitlick PT, Naliboff J, Friedman $W F$. Frank-Starling relationship as an important determinant of fetal cardiac output. Am J Physiol 1976; 231: 495-500.

12 Faber $J J$, Green $T J$, Thornburg $K L$. Arterial blood pressure in the unanaesthetized fetal lamb after changes in fetal blood volume and haematocrit. Quart J Exp Physiol 1974; 59: 241-55.

13 MacDonald AA, Rose J. Heymann MA, Rudolph $A M$. Heart rate response of fetal and adult sheep to hemorrhage stress. Am J Physiol 1980; 239: H789-H793.

14 Rodgers BM, Staroscik RN, Reis RL. Effects of hemorrhage in fetal and newborn lambs. Surgery 1972; 71: 51-5. 
15 Kircheim HR. Systemic arterial baroreceptor reflexes. Physiol Rev 1976; 56: 100-76.

16 Shinebourne EA, Vapaavuori EX, Williams $R L$, Heymann MA, Rudolph AM. Development of barorefex activity in unanaesthctized fetal and neonatal lambs. Circ Res 1972; 31: 710-8.

17 Dawes GS, Lewis BV, Milligan JF, Roach MR, Talner NS. Vasumotor responses in the hind limbs of fetal and newborn lambs to asphyxia and aortic chemoreceptor stimulation. J Physiol 1968; 195: $55-81$.

18 Purves MJ, James IM. Observations on the control of cerebral blood flow in the sheep letus and newbom lamb. Circ Res 1969; 25: 651-67.

19 Reynolds SRM, Mackie JD. Development of chemoreceptor response sensitivity: Studies in foetuses, lambs, and ewes. Am J Physiol 1961; 201: $239-50$.

20 Dawes GS, Duncan SLB, Lewis BV, Merlet $L L$, Owen-Thomas JB, Reeves $J T$. Cyanide stimulation of the systemic arterial chemoreceptors in foetal lambs. J Physiol 1969; 201: 117-28.

21 Rosenberg AA, Jones MD Jr, Traystman RJ, Simmons MA, Molteni RA. Responses of cerebral blood flow to changes in $\mathrm{PCO}_{2}$ in fetal, newborn, and adult sheep. Am J Physiol 1982; 242: H862-H866.

22 Alexander SC. Wollman $H$, Cohen PJ, Chase $P E$, Behar $M$. Cerebrovascular response to $\mathrm{PaCO}_{2}$ during halothane anesthesia in man. J Appl Physiol 1964; 19: 561-5.

23 Faber JJ, Gault CF, Green TJ, Thornburg KL. Fetal blood volume and fetal placental blood flow in lambs. Proc Soc Exp Biol Med 1973; 142: 340-4.
Résumé

On a étudié chez des brebis préparées à long terme l' effet de l'hémorragie aiguë sur les réponses foetales pendant l'anesthésie à l'halothane. On a retiré en moyenne $27.9 \mathrm{~m} ! \mathrm{kg}^{-1}$ de sang foetal, obtenant ainsi une diminution de 20 pour cent de la pression artérielle moyenne qui est revenue aux valeurs de contrôle après 186 secondes. Après la saignée, le débit cardiaque était réduit de 26.1 pour cent, la fréquence cardiaque de 26 pour cent et le flot sanguin rénal, placentaire et musculo-squelettique était réduit de 24.7 pour cent, 38.2 pour cent et 35.3 pour cent respectivement. Le flot cérébral était augmenté de 30 pour cent. La réinfusion du sang perdu corrigea la réduction des flots et l'apport aux organes gastrointestinaux augmenta au-dessus des valeurs de contrôle. Cette étude a montré que les foetus agneaux sont capables de tolérer une perte sanguine aiguë pendant l'anesthésie à l'halothane. Une pression de perfusion adéquate et le flot sanguin aux organes importants comme le cerveau ont été maintenus par une augmentation de la résistance vasculaire périphérique. La compensation cependart était incomplète: Le flot placentaire, les échanges gazelex foeto-maternels et la redistribution du débit cardiaque loin du tractus gastro-intestinal et de la peau étaient menacés. 